\title{
Faktor yang Berpengaruh pada Perilaku Seksual Remaja di Perkotaan dan Pedesaan
}

\section{Factors Associated with The Adolescent Sexual Behavior in Urban and Rural}

\author{
Lisa Suarni $^{1}$, Fitarina ${ }^{2}$, Warjidin Aliyanto ${ }^{3}$ \\ ${ }^{1,2}$ Program Studi Keperawatan Kotabumi, Politeknik Kesehatan Tanjung Karang, Indonesia \\ ${ }^{3}$ Jurusan Kebidanan, Politeknik Kesehatan Tanjung Karang, Indonesia
}

\section{ARTICLE INFO}

\section{Article history}

Received date

13 Nov 2020

Revised date

18 Nov 2020

27 Nov 2020

Accepted date

30 Nov 2020

Keywords:

Rural;

Sexual behavior;

Teenagers;

Urban.

Kata kunci:

Pedesaan;

Perilaku seksual;

Remaja;

Perkotaan.

\author{
ABSTRACT / ABSTRAK
}

The effect of free sex on reproductive health is very real, namely the transmission of sexually transmitted infections (STIs) with all its consequences, a pregnancy outside of marriage and consequently an increase in the incidence of abortion, the psychological pressure to depression. It can be seen that the increasing incidence of STIs, abortion, and depression rates in society is increasing. The research objective was to determine the factors related to Adolescent Sexual Behavior in North Lampung. This study used an explanatory research design with a cross-sectional approach. A sample of 500 people, with a proportion of 250 samples from urban and 250 rural adolescents. The variables related to adolescent sexual behavior in rural areas were the variable of religiosity with a $\mathrm{p}$-value of 0,00 , knowledge with a $\mathrm{p}$-value of 0,00 , sexual attitudes with a p-value of 0,00 , sexual activity with a p-value of 0.06 , social support. with a p-value of 0,00 and in urban areas the related variables were self-esteem with a p-value of 0,10 , religiosity with a p-value of 0,00 , social activity with a p-value of 0,12 , health service attitudes with a $p$ value 0,00 , sexual attitude with a p-value of 0,00 , sexual activity with a p-value of 0,00 , self-confidence with a p-value of 0,24 . Multivariate analysis found that the most dominant factor associated with sexual behavior is sexual attitudes with an $\mathrm{OR}=28,748$. Religiosity, sexual activity, sexual attitudes affect sexual behavior in rural and urban areas. Sexual attitudes are the most dominant factor affecting adolescent sexual behavior in rural and urban areas.

\begin{abstract}
Pengaruh seks bebas bagi kesehatan reproduksi sangat nyata, yaitu tertularnya Infeksi Menular Seksual (IMS) dengan segala akibatnya, hamil di luar nikah dan akibatnya meningkatnya kejadian aborsi, tekanan psikologis sampai dengan depresi. Hal ini dapat dilihat bahwa semakin meningkatnya kejadian IMS, aborsi dan tingkat depresi di masyarakat. Tujuan penelitian untuk mengetahui faktor-faktor yang berhubungan dengan Perilaku Seksual Remaja di Lampung Utara. Penelitian ini menggunakan rancangan penelitian penjelasan (explanatory research) dengan pendekatan belah lintang (cross sectional). Sampel berjumlah 500 orang, dengan proporsi 250 sampel dari perkotaan dan 250 orang remaja pedesaan. Variabel yang berhubungan dengan perilaku seksual remaja dipedesaan adalah variabel relijiusitas dengan $p$-value 0,00 , pengetahuan dengan $p$-value 0,00 , sikap seksual dengan $p$-value 0,00 , aktivitas seksual dengan $p$-value 0,06 , dukungan sosial dengan nilai $p$-value 0,00 dan di wilayah perkotaan variabel yang berhubungan adalah harga diri dengan $p$-value 0,10 , relijiusitas dengan $p$-value 0,00 , aktivitas sosial dengan $p$-value 0,12 , sikap pelayanan kesehatan dengan $\mathrm{p}$ value 0,00 , sikap seksual dengan $p$-value 0,00 , aktivitas seksual dengan $p$-value 0,00 , kepercayaan diri dengan nilai p-value 0,24. Analisis multivariat didapatkan bahwa faktor yang paling dominan berhubungan dengan perilaku seksual adalah sikap seksual.dengan nilai $\mathrm{OR}=28,748$. Religiusitas, aktivitas seksual, sikap seksual berpengaruh terhadap perilaku seksual di pedesaan dan perkotaan. Sikap seksual adalah faktor yang paling dominan berpengaruh terhadap perilaku seksual remaja di wilayah pedesaan dan perkotaan.
\end{abstract}

Corresponding Author:

Lisa Suarni

Program Studi Keperawatan Kotabumi, Politeknik Kesehatan Tanjung Karang, Indonesia

Email: lisakausar@yahoo.co.id 


\section{PENDAHULUAN}

Perilaku seks bebas di Indonesia semakin hari semakin meningkat. Hal ini bertentangan dengan budaya dan agama yang ada di Indonesia. Perilaku seks bebas membawa dampak yang negatif, baik secara sosial maupun untuk kesehatan reproduksi.

Data dari Survei Demografi dan Kesehatan Indonesia (SDKI) 2017 mengungkap sekitar 2\% remaja wanita usia 15-24 tahun dan 8\% remaja pria di rentang usia yang sama, telah melakukan hubungan seksual sebelum menikah. Hasil SDKI (2017) juga menyampaikan tentang kesehatan reproduksi memperlihatkan bahwa $11 \%$ pria setuju adanya hubungan seksual pra nikah, sementara perempuan hanya $2 \%$ yang meneyetujui hubungan seksual pra nikah. (National Population and Family Planning Board Jakarta, Statistics Indonesia Jakarta, Ministry of Health Jakarta, \& USAID, 2018).

Penelitian-penelitian mengenai kaum remaja di Indonesia secara umum menyimpulkan bahwa nilai-nilai hidup kaum remaja sedang dalam proses perubahan. Remaja Indonesia dewasa ini nampak lebih bertoleransi terhadap gaya hidup seksual pranikah (Hatmadji, 1993; Ford, 1997; Hasmi, 2001 dalam Suryoputro, dkk., 2006). Penelitian tersebut memperkuat gambaran adanya peningkatan risiko pada perilaku seksual kaum remaja yang mengindikasikan bahwa 5\%-10\% pria muda usia 15-24 tahun yang tidak/belum menikah, telah melakukan aktifitas seksual yang berisiko (Khisbiyah, 1997; Saparudiin, 1999; Satoto, 1995, Situmorang, 2003, dalam Suryoputro, dkk., 2006).

Hasil dari berbagai penelitian tersebut menunjukkan bahwa peningkatan aktifitas seksual di kalangan kaum remaja, tidak diiringi dengan peningkatan pengetahuan tentang kesehatan seksual dan reproduksi termasuk HIV/AIDS, penyakit menular seksual (PMS) dan alat-alat kontrasepsi (Suryoputro, 2006).

Jumlah kasus HIV dan AIDS yang dilaporkan oleh Dinas Kesehatan Kota Bandar Lampung dari tahun 2005 sampai dengan Maret 2011 ada 214 orang yang terinfeksi HIV dan AIDS di Kota Bandar Lampung, dan kasus Infeksi Menular Seksual/IMS; tahun 2010; Gonorhoe $=76$ kasus, Sifilis=9 Kasus, IMS jenis Lain=355 kasus, dari Januari-Maret 2011; Gonorhoe $=17$ kasus, Servitis; 30 kasus, Sifilis $=2$
Kasus, IMS jenis lain=159 kasus. Dari data tersebut menunjukkan bahwa adanya peningkatan jumlah kasus HIV dan AIDS serta IMS di wilayah Kota Bandar Lampung (Komisi Penganggulangan AIDS, 2011).

Persoalan remaja menjadi masalah yang sangat kompleks dimana terjadi peningkatan jumlah kekerasan seksual setiap tahun. Hal ini tentu berhubungan langsung dengan perilaku seksual, terutama remaja, karena kejadian kekerasan berupa perkosaan dan pelecehan seksual yang paling banyak terjadi pada kelompok usia remaja dan hubungan seksual bebas cenderung lebih banyak terjadi pada daerah pedesaan dibandingkan perkotaan. Peneliti melalui penelusuran pada dinas terkait bahwa data-data tentang perilaku remaja terkait dengan perilaku seksual dan faktor penyebabnya masih sangat minim.

Oleh karena itu tujuan peneliti untuk mengetahui gambaran faktor-faktor yang berhubungan dengan perilaku seksual remaja, faktor yang memengaruhi perilaku seksual remaja perkotaan dan pedesaan, dan faktor yang memengaruhi secara bermakna Perilaku seksual remaja perkotaan dan pedesaan

\section{METODE}

Penelitian ini menggunakan rancangan penelitian penjelasan (explanatory research) dengan pendekatan belah lintang (cross sectional) dengan tujuan mengetahui faktor yang memengaruhi perilaku seksual di Kabupaten Lampung Utara.

Populasi pada penelitian ini adalah seluruh remaja (penduduk usia 15-19 tahun) berjumlah 111.491. Kriteria inklusi sampel adalah remaja berusia 15-19 tahun, belum menikah, bersedia menjadi responden. Perhitungan sampel dengan menggunakan rumus Lemeshow, dengan jumlah sampel minimal adalah 418, namun untuk meningkatkan validitas data dan mengantisipasi kerusakan serta dropout responden, maka sampel yang diambil adalah 500. Untuk proporsi penyebarannya maka, responden yang akan diambil adalah 250 remaja perkotaan dan 250 remaja pedesaan.

Melibatkan 500 sampel remaja perkotaan usia 15-19 tahun yang berasal dari dua latar belakang sosial demografi yang berbeda di Kabupaten Lampung Utara, 250 sampel diambil secara acak bertingkat dari populasi kaum remaja yang berada di pedesaan, dan populasi kaum remaja di perkotaan. Pengumpulan data dari masing-masing kelompok sampel tersebut 
diambil dari sekolah Sekolah Menengah Atas (SMA) di dua kecamatan yang berada di Wilayah Lampung Utara, yaitu kecamatan Kotabumi (mewakili remaja perkotaan), kecamatan Sungkai dan Abung Semuli (mewakili remaja pedesaan). Pengumpulan data penelitian ini menggunakan metode survei (wawancara dan angket/self administered) dengan menggunakan kuesioner terstruktur sebagai instrumen pengumpul data.

Penelitian ini menggunakan variabelvariabel yang dikategorikan dan disusun berdasarkan kerangka teori Social-Learning dari Bandur. Teori, berdasarkan pada pendapat bahwa perilaku manusia dibedakan oleh tiga hal yang saling berhubungan antara faktor personal/individu, faktor lingkungan, dan faktor perilaku. Dalam penelitian ini faktor personal dan lingkungan adalah merupakan variabel bebas, sedangkan faktor perilaku merupakan variabel terikat.

Adapun variabel-variabel tersebut dikategori kedalam faktor-faktor berikut ini:

1. Faktor personal: Variabel-variabel yang termasuk dalam faktor ini adalah pengetahuan mengenai HIV/AIDS, Penyakit Menular Seksual (PMS), aspek-aspek kesehatan reproduksi, sikap terhadap layanan kesehatan seksual \& reproduksi, kerentanan yang dirasakan terhadap resiko kesehatan reproduksi, gaya hidup, pengendalian diri, aktifitas sosial, rasa percaya diri dan variabel-variabel demografi seperti: usia, agama dan status perkawinan.

2. Faktor lingkungan: variabel-variabel yang termasuk didalam faktor ini adalah akses dan kontak dengan sumber-sumber informasi, sosial-budaya, nilai dan norma sebagai pendukung sosial untuk perilaku tertentu.

3. Faktor perilaku: variabel-variabel yang termasuk didalam faktor ini adalah gaya hidup seksual (orientasi seksual, pengalaman seksual, jumlah pasangan), peristiwa-peristiwa kesehatan (PMS, kehamilan, aborsi) dan penggunaan kondom serta alat kontrasepsi.

Adapun cara pengukuran variabel-variabel penelitian dilakukan dengan cara sebagai berikut:

1. Gaya hidup: merupakan pilihan responden terhadap jenis pakaian, makanan, musik, majalah/novel, dan acara TV. Diukur menggunakan rentang nilai lima sampai lima belas yang dikategorikan kedalam empat kategori mulai dari gaya hidup yang sangat tradisional sampai gaya hidup yang sangat modern. Angka/nilai yang lebih tinggi menunjukkan gaya hidup yang lebih modern.

2. Harga diri: diukur dengan menggunakan skala Rosenberg Self-Esteem Scale (Randal, Pratt, \& Bucci, 2015) berisi 10 pernyataan yang bernilai positif (misalnya, saya tidak merasa orang lain lebih baik dari saya) dan negatif (misalnya saya tidak bebas dari rasa malu, rasa bersalah dan menyalahkan) tentang diri sendiri. Variabel tersebut diukur menggunakan teknik skoring dengan rentang nilai $0-4$, dan mengkategorikannya menjadi empat kategori dari rasa harga diri yang buruk/rendah sampai rasa harga diri yang tinggi. (Cronbach Alpha 0,73). Letak Pengendalian diri: diukur dengan skala Rotter 15 berisi 20 hal untuk menilai letak pengendalian diri eksternal (negatif) dan internal (positif) dari individu. Nilai total dibagi menjadi tiga kategori yaitu letak pengendalian diri internal, gabungan internal-external, dan eksternal (Cronbach Alpha: 0,85).

3. Relijiusitas (tingkat keagamaan): merupakan jenis dan tingkat aktifitas yang berhubungan dengan agama (frekuensi berdoa, mengunjungi tempat ibadah, keanggotaan dan keaktifan dalam kegiatan keagaman remaja). Skala pengukuran menggunakan skala Linkert (3 tingkatan) yang terdiri dari "selalu", "kadang2" dan "tidak pernah". Rentang nilainya adalah $0-9$, dimana nilai yang lebih tinggi menunjukkan tingkat relijiusitas/keagamaan yang lebih tinggi.

4. Aktifitas sosial: adalah aktifitas-aktifitas yang dilakukan individu dalam waktu luangnya (pergi kepesta, disko, pub, café, menginap di luar, merokok, minumminuman beralkohol, memakai obat-obatan, membaca/melihat pornografi, dan berkencan dengan penjaja seks komersial/P.S.K/perek/ ciblek, dan sebagainya). Pertanyaan diambil dari perangkat instrumen yang digunakan dalam penelitian sejenis di Thailand (Ford, et al., 1996), diukur menggunakan skala Linkert (4 tingkatan) mulai dari "selalu" sampai "tidak pernah". Rentang nilai adalah 4 sampai 16, dimana nilai yang lebih tinggi mengindikasikan aktifitas sosial yang lebih tinggi.

5. Pengetahuan tentang kesehatan reproduksi, penyakit menular seksual (PMS) dan HIV/AIDS: Pertanyaan diambil dari perangkat kuesioner WHO tentang praktek/perilaku, sikap dan pengetahuan yang digunakan di Ghana pada tahun 1991 (Basen, 1999), untuk menilai pengetahuan menyeluruh mengenai kesehatan reproduksi, 
PMS dan HIV/AIDS. Nilai pengetahuan total dihitung dari jawaban yang benar atas pertanyaan-pertanyaan mengenai pengetahuan. Rentang nilai berkisar dari 0 sampai 15 , dimana nilai yang lebih tinggi mengindikasikan tingkat pengetahuan yang lebih tinggi (Cronbach Alpha: 0,87).

6. Sikap terhadap layanan kesehatan seksual dan reproduksi: merupakan sikap individu terhadap layanan yang berhubungan dengan aspek-aspek seksualitas remaja yang berkaitan dengan keluarga berencana (metode kontrasepsi), HIV/AIDS dan PMS, termasuk juga sumber-sumber informasi yang relevan. Diukur dengan menggunakan skala Linkert (5 tingkatan) mulai dari "sangat setuju" sampai "sangat tidak setuju. Rentang nilai berkisar dari 5 sampai 25 , dimana nilai yang lebih tinggi mengindikasikan sikap yang lebih setuju pada layanan kesehatan tersebut (Cronbach Alpha 0,83).

7. Sikap terhadap seksualitas: merupakan sikap normatif individu terhadap hubungan seksual pra-nikah, penggunaan metode kontrasepsi, penggunaan kondom, pornografi dan homoseksual. Setiap unsur diukur dengan menggunakan skala Reiss, sedangkan jawabannya diukur menggunakan skala Linkert (4 tingkatan) mulai dari "yang sangat setuju" sampai yang "sangat tidak setuju". Nilai akhir dikategorikan ke dalam 4 kategori yang terentang dari tingkah laku "yang sangat normatif" sampai tingkah laku "yang liberal (Cronbach Alpha 0,82).

8. Dukungan Sosial: variabel ini diukur menggunakan sepuluh pernyataan, diantaranya adalah pernyataan yang mengatakan bahwa "menurut teman-teman saya, kondom seharusnya digunakan dalam berhubungan seksual", "menurut "pasangan saya, kondom seharusnya digunakan selama berhubungan seksual", dan "menurut temanteman saya, hubungan seksual pra nikah itu biasa dan dapat diterima". Variabel ini diukur menggunakan skala Linkert (3 tingkatan) mulai dari "yang sangat setuju" sampai "yang sangat tidak setuju". Rentang nilainya adalah 10-30, dimana nilai 30 mengindikasikan adanya dukungan sosial yang paling tinggi (Cronbach Alpha 0,81).

9. Kepercayaan diri: pengukuran variabel ini menggunakan instrumen yang telah disesuaikan dari skala yang dikembangkan oleh (Basen-Engquist, et al., 1999), yang mencakup kepercayaan untuk membuat keputusan mengenai kesehatan reproduktif, kepercayaan untuk menggunakan kondom setiap waktu dan kepercayaan menggunakan kondom sebelum melakukan hubungan seksual. Ukuran ditetapkan dengan menggunakan skala Linkert (3 tingkatan) mulai dari "yang sangat yakin" sampai "yang sangat tidak yakin". Rentang nilainya adalah 15-60, dimana semakin tinggi nilainya menunjukkan semakin tingginya rasa percaya dirinya (Cronbach Alpha 0,85 ).

10. Aktivitas seksual: variabel ini mencakup pengalaman hubungan seksual responden (usia pacar pertama, kedekatan pasangan, dan komitmen emosional) dan pengalaman seksual (pola aktifitas seksual, tekanan yang dialami individu pada saat hubungan seksual pertama kali, penggunaan alat kontrasepsi, jumlah pasangan, jenis hubungan), diukur dengan menggunakan skala rasio dan ordinal.

Pengolahan dan analisis data, dilakukan dengan menggunakan uji Chi-Square, dengan menggunakan 95\% tingkat kepercayaan. Analisis regresi-logistik ganda digunakan untuk menilai kontribusi masing-masing variabel bebas dalam menentukan terjadinya perilaku seksual maupun tingkat kemungkinan (probability) keseluruhan variabel bebas tersebut secara bersama dalam memprediksi terjadinya perilaku seksual.

Sebelum penelitian dimulai, terlebih dahulu dilakukan kaji etik oleh Komite Politeknik Kesehatan Tanjung Karang.

\section{HASIL}

\begin{tabular}{|c|c|c|c|c|c|c|}
\hline $\begin{array}{l}\text { Tabel } 1 . \\
\begin{array}{c}\text { Perilaku } \\
\text { Seksual }\end{array} \\
\end{array}$ & & & & & & la \\
\hline \multirow{2}{*}{$\begin{array}{c}\text { Perilaku } \\
\text { Seksual }\end{array}$} & \multicolumn{2}{|c|}{$\begin{array}{l}\text { Remaja } \\
\text { Kota }\end{array}$} & \multicolumn{2}{|c|}{$\begin{array}{l}\text { Remaja } \\
\text { Desa }\end{array}$} & \multicolumn{2}{|c|}{ JUMLAH } \\
\hline & n & $\%$ & $\mathrm{n}$ & $\%$ & $\mathbf{n}$ & $\%$ \\
\hline $\begin{array}{l}\text { Tidak } \\
\text { Berisiko }\end{array}$ & 188 & 90 & 175 & 83,7 & 363 & 86,84 \\
\hline Berisiko & 21 & 10 & 34 & 16,3 & 55 & 13,16 \\
\hline Jumlah & 209 & 100 & 209 & 100 & 418 & 100 \\
\hline
\end{tabular}

Dari tabel 1 dapat dilihat terdapat 21 $(10 \%)$ remaja perkotaaan yang berperilaku seksual berisiko, dan 34 (16,3\%) pada remaja pedesaan. Jika dibandingkan lebih banyak pada remaja pedesaan berperilaku seksual berisiko dibanding dengan remaja perkotaan. 
Tabel 2. Karakteristik Faktor yang Berhubungan dengan Perilaku Seksual Remaja di Perkotaan dan Pedesaan

\begin{tabular}{|c|c|c|c|c|}
\hline \multirow{2}{*}{ Variabel } & \multicolumn{2}{|c|}{ Perkotaan } & \multicolumn{2}{|c|}{ Pedesaan } \\
\hline & $\mathbf{n}$ & $\%$ & $\mathbf{n}$ & $\%$ \\
\hline \multicolumn{5}{|c|}{ Jenis Kelamin } \\
\hline Laki & 68 & 32,5 & 78 & 37,3 \\
\hline Perempuan & 141 & 67,46 & 131 & 62,6 \\
\hline \multicolumn{5}{|l|}{ Gaya Hidup } \\
\hline Tradisional & 0 & 0 & 19 & 9,09 \\
\hline Moderen & 209 & 100 & 190 & 90,9 \\
\hline \multicolumn{5}{|l|}{ Harga Diri } \\
\hline Tinggi & 162 & 77,5 & 154 & 73,6 \\
\hline Rendah & 47 & 22,5 & 55 & 26,3 \\
\hline \multicolumn{5}{|l|}{ Relijiusitas } \\
\hline Tinggi & 182 & 87,01 & 154 & 73,68 \\
\hline Rendah & 27 & 12,91 & 55 & 26,31 \\
\hline \multicolumn{5}{|c|}{ Aktifitas Sosial } \\
\hline Tinggi & 13 & 6,22 & 13 & 6,22 \\
\hline Rendah & 196 & 93,7 & 196 & 93,7 \\
\hline \multicolumn{5}{|c|}{ Pengetahuan } \\
\hline Tinggi & 100 & 47,84 & 135 & 64,50 \\
\hline Rendah & 109 & 52,15 & 74 & 35,40 \\
\hline \multicolumn{5}{|c|}{ Sikap terhadap Pelayanan Kesehatan } \\
\hline Setuju & 174 & 83,25 & 154 & 73,68 \\
\hline Tidak Setujı & 35 & 16,74 & 55 & 26,31 \\
\hline \multicolumn{5}{|c|}{ Sikap Seksual } \\
\hline Normatif & 186 & 88,99 & 176 & 84,21 \\
\hline Liberal & 23 & 11,00 & 33 & 15,78 \\
\hline \multicolumn{5}{|c|}{ Aktifitas Seksual } \\
\hline Baik & 189 & 90,43 & 178 & 85,16 \\
\hline Tidak Baik & 20 & 9,56 & 31 & 14,83 \\
\hline \multicolumn{5}{|c|}{ Dukungan Sosial } \\
\hline Tinggi & 20 & 9,56 & 42 & 20,09 \\
\hline Rendah & 189 & 90,43 & 167 & 79,90 \\
\hline \multicolumn{5}{|c|}{ Kepercayaan Diri } \\
\hline Tinggi & 187 & 89,47 & 152 & 72,72 \\
\hline Rendah & 22 & 10,52 & 57 & 27,27 \\
\hline
\end{tabular}

Berdasarkan tabel 2 beberapa faktor dari jenis kelamin menunjukkan adanya jumlah yang seimbang antara laki-laki dan perempuan, pada faktor gaya hidup remaja pedesaan $100 \%$ menerapkan gaya hidup modern, sedang di pedesaan terdapat 9,09\% menerapkan gaya hidup tradisional dan sebagian besar menerapkan gaya hidup modern, pada faktor harga diri antara remaja perkotaan dan pedesaan cenderung sama memiliki harga diri yang tinggi $(77,5 \%: 73,6 \%)$, faktor relijiusitas memperlihatkan bahwa remaja perkotaan lebih cenderung memiliki relijiusitas yang tinggi dibanding dengan remaja pedesaan $(87,01 \%: 73,68 \%)$, faktor aktifitas sosial antara remaja pedesaan dan perkotaan sama sama rendah $(93,7 \%)$, faktor pengetahuan remaja perkotaan memiliki pengetahuan yang lebih rendah dari remaja pedesaan $(47,84 \%: 64,50 \%)$, faktor sikap terhadap pelayanan kesehatan remaja perkotaan lebih banyak yang setuju disbanding dengan remaja pedesaan $(83,25 \%: 73,68 \%)$, sikap seksual pada remaja pedesaan lebih liberal dari remaja perkotaan $(15,78 \%$ : $11 \%)$, faktor aktifitas seksual masih terdapat aktifitas seksual yang negatif pada remaja perkotaan maupun pedesaan dan cenderung lebih banyak yang negatif pada remaja pedesaan $(9,56 \%: 14,83 \%)$, faktor dukungan sosial memperlihatkan dukungan sosial yang lebih rendah pada remaja perkotaan $(90,43 \%$ : $79,90 \%)$ dan faktor kepercayaan diri pada remaja perkotaan dan pedesaan memperlihatkan bahwa remaja pedesaan memiliki kepercayaan diri yang lebih rendah $(27,27 \%: 10,52 \%)$. 
Tabel 3. Faktor yang Memengaruhi Perilaku Seksual Remaja di Daerah Perkotaan dan Pedesaan

\begin{tabular}{|c|c|c|c|c|c|c|c|c|c|c|c|}
\hline \multirow{4}{*}{ Variabel } & \multirow{4}{*}{ Kategori } & \multicolumn{5}{|c|}{ Remaja Perkotaan } & \multicolumn{5}{|c|}{ Remaja Pedesaan } \\
\hline & & \multicolumn{4}{|c|}{ Perilaku Seksual } & \multirow{3}{*}{$p$-value } & \multicolumn{4}{|c|}{ Perilaku Seksual } & \multirow{3}{*}{$p$-value } \\
\hline & & \multicolumn{2}{|c|}{ Tidak berisiko } & \multicolumn{2}{|c|}{ Berisiko } & & \multicolumn{2}{|c|}{ Tidak berisiko } & \multicolumn{2}{|c|}{ Berisiko } & \\
\hline & & $\mathbf{n}$ & $\%$ & $\mathbf{n}$ & $\%$ & & $\mathbf{n}$ & $\%$ & $\mathbf{n}$ & $\%$ & \\
\hline \multirow{2}{*}{ Jenis kelamin } & Laki-laki & 62 & 91,2 & 6 & 8,8 & \multirow{2}{*}{0,8} & 64 & 82,1 & 14 & 17,9 & \multirow{2}{*}{0,70} \\
\hline & Perempuan & 126 & 89,4 & 15 & 10,6 & & 110 & 84,6 & 21 & 15,4 & \\
\hline \multirow{2}{*}{ Gaya hidup } & Tradisional & 0 & 0 & 0 & 0 & \multirow[b]{2}{*}{0,70} & 17 & 89,5 & 2 & 10,5 & \multirow{2}{*}{0,74} \\
\hline & Modern & 188 & 90 & 21 & 10 & & 158 & 83,2 & 32 & 16,8 & \\
\hline \multirow{2}{*}{ Harga diri } & Tinggi & 128 & 93,2 & 34 & 10,8 & \multirow{2}{*}{0,11} & 131 & 85,1 & 23 & 14,9 & \multirow{2}{*}{0,39} \\
\hline & Rendah & 37 & 78,7 & 10 & 20,6 & & 44 & 80 & 11 & 20 & \\
\hline \multirow[b]{2}{*}{ Religiusitas } & Tinggi & 176 & 96,7 & 6 & 3,3 & \multirow{2}{*}{0,00} & 143 & 92,9 & 11 & 7,1 & \multirow[b]{2}{*}{0,00} \\
\hline & Rendah & 12 & 44,4 & 15 & 55,6 & & 32 & 58,2 & 23 & 41,8 & \\
\hline \multirow{2}{*}{ Aktivitas sosial } & Tinggi & 10 & 76,9 & 3 & 23,1 & \multirow{2}{*}{0,12} & 10 & 76,9 & 3 & 23,1 & \multirow{2}{*}{0,44} \\
\hline & Rendah & 178 & 90,8 & 18 & 9,1 & & 165 & 84,2 & 31 & 15,8 & \\
\hline \multirow[b]{2}{*}{ Pengetahuan } & Tinggi & 90 & 90 & 10 & 10 & \multirow{2}{*}{1,00} & 127 & 94,1 & 8 & 5,9 & \multirow{2}{*}{0,00} \\
\hline & Rendah & 98 & 89,9 & 11 & 10,1 & & 48 & 64,9 & 26 & 33,1 & \\
\hline Sikan yankes & Setuju & 170 & 93,4 & 4 & 6,6 & 000 & 133 & 86,4 & 21 & 13,6 & 002 \\
\hline SIкар yankes & Tdk setuju & 18 & 66,7 & 17 & 33,3 & & 42 & 76,4 & 13 & 23,6 & 92 \\
\hline Sikan ckenul & Normatif & 182 & 97,8 & 4 & 2,2 & 00 & 160 & 90.9 & 16 & 9,1 & 000 \\
\hline SIKap seksual & Liberal & 6 & 26,1 & 17 & 73,9 & 0,00 & 15 & 45,5 & 17 & 54,5 & 0,00 \\
\hline & Baik & 172 & 91 & 17 & 9 & & 155 & 87,1 & 23 & 12,9 & \\
\hline A & Tdk baik & 16 & 80 & 4 & 20 & & 20 & 64,5 & 11 & 35,5 & ,06 \\
\hline Dukungan sos & Tinggi & 18 & 90 & 2 & 10 & & 21 & 50 & 21 & 50 & \\
\hline Dukungan sos & Rendah & 170 & 89,9 & 19 & 10,1 & 1,00 & 154 & 92,2 & 13 & 7,8 & 0,00 \\
\hline & Tinggi & 170 & 90,9 & 17 & 9,1 & & 125 & 82,2 & 27 & 17,8 & \\
\hline dirr & Rendah & 18 & 81,8 & 4 & 18,2 & 0,24 & 50 & 87,7 & 7 & 12,3 &,, 40 \\
\hline
\end{tabular}

Berdasarkan tabel 3 dapat dilihat bahwa faktor yang berhubungan dengan perilaku seksual di daerah perkotaan adalah variabel harga diri ( $p$-value 0,10$)$, relijiusitas ( $p$-value 0,00 ), aktivitas sosial (p-value 0,12), sikap pelayanan kesehatan ( $p$-value 0,00), sikap seksual dengan $p$-value 0,00 , aktivitas seksual dengan $p$-value 0,00 , kepercayaan diri dengan nilai $p$-value 0,24 sedangkan untuk daerah pedesaan adalah variabel relijiusitas dengan $p$ value 0,00 , pengetahuan dengan $p$-value 0,00 , sikap seksual dengan $p$-value 0,00 , aktivitas seksual dengan $p$-value 0,06 dukungan sosial dengan nilai $p$-value 0,00 .

Variabel yang tidak berhubungan pada remaja kota adalah jenis kelamin dengan $p$-value 80, gaya hidup dengan p-value 0,70 , pengetahuan dengan $p$-value 1,00, dukungan sosial dengan $p$-value 1,00 , sedangkan untuk remaja desa adalah jenis kelamin dengan $p$-value 0,70 , gaya hidup dengan $p$-value 0,74 , harga diri dengan $p$-value 0,39 , aktivitas sosial dengan $p$ value 0,44 , sikap pelayanan kesehatan dengan $p$ value 0,92 , kepercayaan diri dengan $p$-value 0,4 .
Tabel 4. Faktor yang Memengaruhi Perilaku Seksual Remaja di Daerah Perkotaan dan Pedesaan

\begin{tabular}{lcr}
\hline \multicolumn{1}{c}{ Variabel } & p-value & OR (95\% CI) \\
\hline Harga Diri & 0,10 & $\begin{array}{r}2,790 \\
(0,482-16,156)\end{array}$ \\
\hline Relijiusitas & 0,00 & $\begin{array}{r}22,796 \\
(3,74-138,747)\end{array}$ \\
\hline Aktivitas Sosial & 0,12 & $\begin{array}{r}2,038 \\
(0,148-28,112)\end{array}$ \\
\hline $\begin{array}{l}\text { Sikap terhadap } \\
\text { yankes }\end{array}$ & 0,00 & $\begin{array}{r}2,595 \\
(0,331-20,318)\end{array}$ \\
\hline Sikap Seksual & 0,00 & $\begin{array}{r}76,830 \\
(12,62-467,408)\end{array}$ \\
\hline Aktifitas Seksual & 0,12 & $\begin{array}{r}2,247 \\
(0,382-27,575)\end{array}$ \\
\hline Kepercayaan diri & 0,24 & $\begin{array}{r}0,747 \\
(0,010-54,408)\end{array}$ \\
\hline
\end{tabular}

Dari hasil tabel 4 ditemukan variabel bebas dengan nilai $p$-value $>0,05$ adalah variabel harga diri, aktifitas sosial, aktifitas seksual, kepercayaan diri sehingga harus dikeluarkan dari tahapan analisis multivariat secara berurutan berdasakan nilai $p$-value yang terbesar. Selanjutnya variabel-variabel lain kembali dianalisis hingga ditemukan hasil akhir tahapan analisis multivariat. 


\section{PEMBAHASAN}

\section{Perilaku Seksual Remaja di Pedesaan dan Perkotaan}

Beberapa penelitian yang juga meneliti faktor yang berhubungan dengan perilaku seksual remaja diantaranya penelitian Thompson, et al., (2018) yang memperoleh hasil remaja pedesaan dilaporkan lebih banyak pernah melakukan hubungan seks $(24,0 \%)$ dibandingkan dengan remaja perkotaan $(19,7 \%)$, Tidak ada perbedaan signifikan yang diamati untuk sebagian besar perilaku seksual yang dinilai. Meskipun demikian, peserta perkotaan cenderung untuk melakukan hubungan seks tanpa kondom di tahun berikutnya dibandingkan dengan peserta pedesaan $(\mathrm{OR}=0,76$, 95\% CI 0,63-0,92). Secara keseluruhan, tidak ada perbedaan besar dalam perilaku seksual antara remaja pedesaan dan perkotaan di Florida. Namun, niat seksual berbeda antara remaja pedesaan dan perkotaan; khususnya, remaja pedesaan lebih cenderung untuk melakukan hubungan seks tanpa kondom di tahun berikutnya dibandingkan dengan remaja perkotaan. Memahami perbedaan spesifik dapat menginformasikan kontrasepsi dan intervensi kesehatan seksual di kalangan pemuda pedesaan. (Thompson, et al., 2018).

\section{Faktor yang Berhubungan dengan Perilaku Seksual Remaja di Perkotaan dan Pedesaan}

Gaya hidup modern tidak lagi tergantung pada apakah hidup di lingkungan pdesaan dan perkotaan, dengan kemajuan informasi dan era revolusi industri 4,0 telah membawa masyarakat terutama remaja cenderung menerima informasi dengan mudah, yang dampaknya adalah pada gaya hidup Penelitian Regis M.F, et.al (2016) yang meneliti remaja usia 14-19 tahun di Brasil, menyatakan bahwa remaja tinggal di daerah pedesaan kurang terkena perilaku menetap, memilih waktu luang yang lebih aktif, dan memiliki tingkat fisik yang lebih tinggi aktivitas. Tempat tinggal dan pekerjaan mungkin memainkan peran utama gaya hidup remaja. Penelitian Susanto, et al., (2016) yang menguji efek klinik kesehatan ramah berbasis masyarakat/ Community-Based Friendly Health Clinic (CFHC) pada remaja di Indonesia, terdapat perbedaan hasil, pada remaja pedesaan dan perkotaan, dimana CFHC berpengaruh pada pengetahuan, sikap dan keterampilan remaja di pedesaan, namun hanya berpengaruh terhadap pengetahuan pada remaja di perkotaan.
Faktor harga diri menunjukkan bahwa remaja perkotaan memiliki harga diri yang lebih tinggi dibanding dengan remaja pedesaan Hal ini sejalan dengan penelitian Shukla, et al, yang meneliti remaja-remaja di Distrik Ludhiana, Punjab yang meneliti tiga ratus remaja usia 1618. (Shukla, Prachi; Kang, 2017). Penelitian Kemigisha, et al, yang menilai kesejahteraan seksual dalam arti luas, yaitu, citra tubuh, harga diri, dan norma-norma kesetaraan gender, dan faktor-faktor terkait pada remaja muda di Uganda. Sebuah survei cross-sectional dari remaja usia 10-14 tahun di sekolah dilakukan antara Juni dan Juli 2016, mencatat skor tinggi untuk harga diri dan citra tubuh tetapi skor moderat pada gender norma yang adil. Anak perempuan memiliki skor yang lebih tinggi dibandingkan dengan anak laki-laki untuk semua hasil. Usia dan makhluk yang lebih tinggiaktif secara seksual dikaitkan dengan skor yang lebih rendah pada norma-norma kesetaraan gender. Kesetaraan genderskor norma menurun dengan bertambahnya usia remaja. Seksualitas yang komprehensif dan tepat waktu program pendidikan yang berfokus pada perbedaan dan norma gender dianjurkan (Kemigisha, et al., 2018).

Penelitian lain tentang harga diri remaja dilakukan oleh Jackman and MacPhee, didapat informasi bahwa menjelaskan bagaimana konsep diri mungkin menjadi faktor penghindaran risiko remaja. Secara khusus, baik orientasi masa depan dan harga diri yang sehat dapat berfungsi sebagai faktor pelindung terhadap keterlibatan dalam perilaku berisiko (Jackman \& MacPhee, 2017).

Faktor relijiusitas remaja perkotaan lebih tinggi dibanding pedesaan, dampak dari revolusi industri adalah begitu bebasnya konten-konten ponografi dapat diakses oleh remaja, tanpa benteng agama yang kuat remaja akan cenderung mengakses situs-situs pornografi, penelitian MacInnisa dan Hodson membuktikan bahwa semakin banyak individu yang religius lebih cenderung percaya bahwa nilai-nilai moral, ras, dan keuangan (bukan agama) berdampak pada sejauh mana konten seksual dilihat secara online (MacInnis \& Hodson, 2016) Semakin banyak orang yang beragama juga memiliki keyakinan negatif tentang melihat konten seksual secara online dan menganggap pandangan seperti itu lebih bermasalah daripada masalah sosial terkemuka lainnya (misal rasisme, kekerasan senjata). Akhirnya, mereka yang beragama lebih tinggi melaporkan kurang melihat konten seksual secara online. Diantara sekelompok individu yang relatif tinggi dalam religiusitas atau fundamentalisme agama yang melaporkan 
melihat konten seksual online, relijiusitas dikaitkan dengan perasaan negatif tentang perilaku ini dan motif yang dilaporkan sendiri untuk memantau amoralitas masyarakat (MacInnis \& Hodson, 2016), (Smith \& Okech, 2016). Relijiusitas juga memengaruhi durasi pernikahan pada wanita Yahudi (Lazar, 2017).

Aktifitas sosial bagi masyarakat pedesaan dan perkotaan cenderung sama, mereka melakukan aktifitas-aktifitas yang dilakukan dalam waktu luangnya (pergi ke pesta, disko, pub, café, menginap di luar, merokok, minumminuman beralkohol, memakai obat-obatan, membaca/melihat pornografi, dan berkencan dengan penjaja seks komersial/P.S.K/perek/ ciblek, dan sebagainya), hanya ada $6,3 \%$ baik remaja di perkotaan maupun pedesaan melakukan aktifitas sosial seperti di atas. Penelitian Van Hecke memperlihatkan aktifitas negatif pada Public Open Space dipengaruhi oleh faktor fisik dan sosial, diantaranya berolah raga, aksesibilitas internet, dll (Van Hecke, et al., 2018)

Penelitian Magalhães, et al., menyimpulkan berlatih olahraga pada remaja awal mungkin penting untuk mempromosikan pemeliharaan aktifitas fisik tinggi. Lingkungan perkotaan di sekitar tempat tinggal tidak memengaruhi perubahan dalam aktifitas fisik dalam mengisi waktu senggang (Magalhães, Pina, \& Ramos, 2017).

Masih banyak remaja yang memiliki pengetahuan yang rendah tentang kesehatan reproduksi, penyakit menular seksual (PMS) dan HIV/AIDS, hasil penelitian menggambarkan remaja perkotaan lebih banyak berpengetahuan rendah dibanding dengan remaja pedesaan. Penelitian Nguyen, et al, yang menilai pengetahuan tentang PMS dan faktor-faktor terkait di antara pasien dermatologis. Sebuah studi cross-sectional dilakukan di antara 622 pasien di Rumah Sakit Dermatologi dan Venereologi Nasional (NHD) Vietnam, diperoleh kesimpulan bahwa hidup dengan pasangan, usia muda, dan memperoleh pengetahuan tentang PMS melalui internet, jejaring sosial, dan staf kesehatan berhubungan positif dengan memiliki pengetahuan yang lebih baik tentang PMS. Berdasarkan hasil penelitian ini, pendidikan sebaya, percakapan informal dalam kelompok, kampanye komunitas massal melalui Internet dan jejaring sosial, dan penggunaan penyedia layanan kesehatan online harus dipromosikan untuk meningkatkan kesadaran tentang PMS (Nguyen, et al., 2019).

Faktor sikap seksual pada remaja pedesaan lebih liberal dari remaja perkotaan, beberapa penelitan menggambarkan tentang sikap seksual remaja antara lain penelitian terhadap remaja di India menunjukkan nilai rata-rata untuk sikap seksual adalah 37,99 $( \pm 6,11)$, menunjukkan bahwa para peserta memiliki sikap liberal terhadap seksualitas. Analisis item menunjukkan bahwa $61 \%$ dari mereka setuju bahwa melakukan hubungan seks di luar nikah selalu buruk; $75 \%$ setuju bahwa aborsi harus selalu dengan izin; 55\% setuju bahwa keperawanan harus didorong dalam masyarakat kita dan $52 \%$ dari mereka tidak setuju pada aborsi bukanlah kejahatan. (Dutt \& Manjula, 2017). Penelitian di Maharasthra menyimpulkan bahwa dari 400 remaja wanita yang berpartisipasi dalam penelitian, pengetahuan dan sikap masing-masing $164(41,0 \%)$ dan $315(78,8 \%)$ peserta adalah miskin. Praktek menstruasi dari $271(67,8 \%)$ peserta adalah buruk. Pengetahuan, sikap dan praktik mengenai kesehatan reproduksi dan seksual lebih dari separuh partisipan miskin. Untuk pengembangan sikap dan praktik yang sehat, usia dan gender adalah pendidikan kesehatan yang tepat adalah suatu keharusan. (Phulambrikar, 2018).

Faktor aktifitas seksual memperlihatkan masih terdapat aktifitas seksual yang negatif pada remaja perkotaan maupun pedesaan dan cenderung lebih banyak yang negatif pada remaja pedesaan, penelitian yang dilakukan oleh Rogers berupa analisis terhadap tiga puluh studi peer review menghasilkan temuan hubungan yang konsisten antara komunikasi seksual orang tuaremaja dengan sikap seksual remaja dan pelaksanaan seks aman yang pada gilirannya dapat memengaruhi niat dan perilaku seksual mereka (Rogers, 2017).

\section{Faktor yang Memengaruhi Perilaku Seksual Remaja di Daerah Perkotaan dan Pedesaan}

Berdasarkan hasil akhir tahapan analisis multivariat diketahui bahwa variabel yang berhubungan secara bermakna dengan perilaku seksual adalah variabel relijuitas, sikap terhadap pelayanan kesehatan, dan sikap seksual.

Hasil analisis variabel relijiusitas diperoleh $\mathrm{OR}=26,030$ yang artinya repsonden dengan relijuisitas rendah beresiko 26 dibandingkan responden dengan relijusitas tinggi setelah dikontrol oleh variabel relijiusitas, sikap terhadap pelayanan kesehatan dan sikap seksual

Hasil analisis variabel sikap terhadap pelayanan kesehatan $\mathrm{OR}=85,184$ yang artinya repsonden dengan sikap seksual liberal beresiko 85 kali dibandingkan responden dengan sikap seksual normatif setelah dikontrol oleh variabel 
relijuisitas, sikap terhadap pelayanan kesehatan, dan sikap sikap seksual

Dari hasil analisis ketikga variabel, diketahui variabel yang meliki nilai OR paling besar adalah variabel sikap seksual dengan nilai $\mathrm{OR}=84,184$. Berarti variabel sikap seksual adalah variabel yang paling besar pengaruhnya terhadap perilaku seksual atau dengan kata lain faktor yang paling dominan berhubungan dengan perilaku seksual adalah sikap seksual.

Dari hasil ditemukan variabel bebas dengan nilai $p$-value $>0,05$ adalah variabel aktivitas sosial sehingga harus dikeluarkan dari tahapan analisis multivariat secara berurutan berdasakan nilai p-value yang terbesar. Selanjutnya variabel-variabel lain kembali dianalisis hingga ditemukan hasil akhir tahapan analisis multivariat yang dapat dilihat sebagai berikut:

Berdasarkan hasil akhir tahapan analisis multivariat diketahui bahwa variabel yang berhubungan secara bermakna dengan perilaku seksual adalah variabel relijiusitas, pengetahuan, sikap seksual dan dukungan sosial.

Hasil analisis variabel religiusitas diperoleh $\mathrm{OR}=11,098$ yang artinya repsonden dengan relijuisitas rendah beresiko 11 dibandingkan responden dengan relijusitas tinggi setelah dikontrol oleh variabel religiusitas, pengetahuan, sikap sikap seksual dan dukungan sosial

Hasil analisis variabel pengetahuan $\mathrm{OR}=24,568$ yang artinya repsonden dengan pengetahuan yang rendah lebih bersiko 24 kali dibandingkan responden dengan pengetahuan yang tinggi setelah dikontrol oleh variabel relijuisitas, sikap seksual dan dukungan sosial.

Hasil analisis variabel sikap seksual $\mathrm{OR}=28,478$ yang artinya repsonden dengan sikap seksual liberal lebih beresiko 28 kali dibandingkan dengan responden sikap seksual normatif setelah dikontrol oleh variabel relijiusitas, pengetahuan, dan dukungan sosial.

Hasil analisis variabel dukungan sosial $\mathrm{OR}=0,25$ yang artinya repsonden dengan dukungan sosial rendah lebih beresiko 0,2 kali dibandingkan dengan responden dengan dukungan sosial tinggi setelah dikontrol oleh variabel relijiusitas, pengetahuan, dan sikap seksual.

Dari hasil analisis keempat variabel, diketahui variabel yang meliki nilai OR paling besar adalah variabel sikap seksual dengan nilai $\mathrm{OR}=28,478$. Berarti variabel sikap seksual adalah variabel yang paling besar pengaruhnya terhadap perilaku seksual atau dengan kata lain faktor yang paling dominan berhubungan dengan perilaku seksual adalah sikap seksual.

Hasil penelitian telah menunjukkan bahwa faktor yang berhubungan dengan perilaku seksual remaja pada perkotaan dan pedesaan yang paling dominan adalah relijiusitas, sikap terhadap seksualitas, sikap terhadap pelayanan kesehatan dominan berhubungan pada remaja kota, sedangkan remaja desa tidak dominan. Ada 2 faktor yang dominan pada remaja desa yaitu pengetahuan dan dukungan sosial, tetapi tidak dominan pada remaja kota.

Penelitian Landor \& Halpern, menyimpulkan sikap perkawinan memiliki efek peredam yang secara signifikan lebih kuat pada perilaku seksual berisiko kulit Afrika-Amerika dan Asia yang lebih muda dibandingkan dengan kulit mereka yang lebih gelap. Nada kulit juga secara langsung meramalkan jumlah pasangan dan pasangan bersamaan di antara pria AfrikaAmerika dan Asia (Landor \& Halpern, 2016).

Hasil penelitian Lee dan Kim, menunjukkan bahwa pengalaman hubungan seksual lebih sering terjadi pada responden yang lebih terbuka tentang sikap seksual, mereka yang ibunya lebih terbuka terhadap perilaku seksual, dan mereka yang kurang depresi. Pengalaman hubungan seksual penting untuk memengaruhi masa dewasa mendatang pada mahasiswa. Studi ini menunjukkan bahwa perlu untuk mengembangkan secara sistematis program pendidikan seksual di universitas dan masyarakat (Lee \& Kim, 2017).

Beberapa penelitian tentang perilaku seksual remaja di Indonesia membuktikan bahwa peran teman sebaya, pendampingan orang tua, paparan media pornografi dan pengetahuan tentang seksual adalah faktor yang berpengaruh pada perilaku seksual remaja, terutama perilaku yang cenderung negatif (Rianto, dkk, 2018; Gustina, 2017; Farakhiyah, Raharjo, \& Apsari, 2018; Istiqomah \& Notobroto, 2017; Latif, dkk, 2019).

\section{SIMPULAN}

Perilaku seksual pada remaja pedesaan lebih berisiko dibanding dengan remaja perkotaan. Variabel yang berhubungan dengan perilaku seksual di daerah perkotaan adalah harga diri dengan, relijiusitas, aktivitas sosial, sikap pelayanan kesehatan, sikap, aktivitas seksual, kepercayaan diri, sedangkan variabel yang tidak berhubungan adalah jenis kelamin gaya hidup, pengetahuan, dukungan sosial, diantara variabel tersebut yang dominan adalah sikap seksual, 
variabel yang berhubungan dengan perilaku seksual di daerah pedesaan adalah relijiusitas, pengetahuan, sikap seksual, aktivitas seksual, dukungan sosial sedangkan variabel yang tidak berhubungan adalah jenis kelamin, gaya hidup,

\section{DAFTAR PUSTAKA}

Basen-Engquist, K., Mâsse, L. C., Coyle, K., Kirby, D., Parcel, G. S., Banspach, S., \& Nodora, J. (1999). Validity of scales measuring the psychosocial determinants of HIV/STD-related risk behavior in adolescents. Health Education Research, 14(1), 25-38.

https://doi.org/10.1093/her/14.1.25

Dutt, S., \& Manjula, M. (2017). Sexual knowledge, attitude, behaviors and sources of influences in Urban college youth: A study from India. Indian Journal of Social Psychiatry, 33(4), 319. https://doi.org/10.4103/0971-9962.218602

Rianto, E., Priwahyuni, Y. P., \& Saputra, B. (2018). Determinan Perilaku Seksual Remaja di SMA Negeri 1 Siak Kecil Kabupaten Bengkalis Tahun 2017. The Indonesian Journal of Health Science, 10(1).

Farakhiyah, R., Raharjo, S. T., \& Apsari, N. C. (2018). Perilaku Seksual Remaja Dengan Disabilitas Mental. Share: Social Work Journal, $\quad 8(1), \quad 114$. https://doi.org/10.24198/share.v8i1.18122

Ford N, Kittisuksathit S. (1996). Youth Sexuality: The Sexual Awareness, Lifestyles and Related-Health Service Needs of Young, Single, Factory Workers in Thailand. Research report. Bangkok: ISPR Mahidol University.

Gustina, E. (2017). Komunikasi OrangtuaRemaja Dan Pendidikan Orangtua Dengan Perilaku Seksual Berisiko Pada Remaja. Unnes Journal of Public Health, 6(2), 131. https://doi.org/10.15294/ujph.v6i2.13734

Istiqomah, N., \& Notobroto, H. B. (2017). Pengaruh Pengetahuan, Kontrol Diri terhadap Perilaku Seksual Pranikah di Kalangan Remaja SMK di Surabaya. Jurnal Biometrika Dan Kependudukan, 5(2), 125. https://doi.org/10.20473/jbk.v5i2.2016.125 $-134$

Jackman, D. M., \& MacPhee, D. (2017). SelfEsteem and Future Orientation Predict Adolescents' Risk Engagement. Journal of Early Adolescence, 37(3), 339-366. harga diri, aktivitas sosial, sikap pelayanan kesehatan, dan kepercayaan diri, diantara variabel tersebut yang paling dominan adalah sikap seksual.

Kemigisha, E., Nyakato, V. N., Bruce, K., Ruzaaza, G. N., Mlahagwa, W., Ninsiima, A. B., ... Michielsen, K. (2018). Adolescents' sexual wellbeing in Southwestern Uganda: A cross-sectional assessment of body image, self-esteem and gender equitable norms. International Journal of Environmental Research and Public Health, 15(2). https://doi.org/10.3390/ijerph15020372

Komisi Penanggulangan AIDS (KPA). (2011). Pedoman Program Pencegahan HIV Melalui Transmisi Seksual. Jakarta

Landor, A. M., \& Halpern, C. T. (2016). The Enduring Significance of Skin Tone: Linking Skin Tone, Attitudes Toward Marriage and Cohabitation, and Sexual Behavior. Journal of Youth and Adolescence, 45(5), 986-1002. https://doi.org/10.1007/s10964-016-0456-8

Latif, I., Fitriyani, D., \& . D. (2019). Faktor Internal Dan Eksternal Yang Mempengaruhi Perilaku Seksual Lelaki Seks Dengan Lelaki (Lsl) Pada Remaja Di Kabupaten Indramayu. Jurnal Kesehatan Indra Husada, 6(2), 1. https://doi.org/10.36973/jkih.v6i2.134

Lazar, A. (2017). Moderating Effects of Religiousness and Marriage Duration on the Relation Between Sexual and Marital Satisfaction Among Jewish Women. Archives of Sexual Behavior, 46(2), 513523. https://doi.org/10.1007/s10508-0160847-7

Lee, E. M., \& Kim, K. Y. (2017). The effect of college students' sexual attitude, parents' sexual attitude, and depression on sexual relations experience. Stress 㸴究, 25 (3), 155-161.

MacInnis, C. C., \& Hodson, G. (2016). Surfing for Sexual Sin: Relations Between Religiousness and Viewing Sexual Content Online. Sexual Addiction and Compulsivity, 23(2-3), 196-210. https://doi.org/10.1080/10720162.2015.11 30000

Magalhães, A. P. T. da F., Pina, M. de F. R. P. 
de, \& Ramos, E. da C. P. (2017). The Role of Urban Environment, Social and Health Determinants in the Tracking of LeisureTime Physical Activity Throughout Adolescence. Journal of Adolescent Health, 60(1), 100-106. https://doi.org/10.1016/j.jadohealth.2016.0 8.015

National Population and Family Planning Board Jakarta, I., Statistics Indonesia Jakarta, I., Ministry of Health Jakarta, I., \& USAID. (2018). INDONESIA DEMOGRAPHIC AND HEALTH SURVEY 2017: ADOLESCENT REPRODUCTIVE HEALTH KEY INDICATORS REPORT. Jakarta.

Nguyen, S. H., Dang, A. K., Vu, G. T., Nguyen, C. T., Le, T. H. T., Truong, N. T., ... Ho, R. C. M. (2019). Lack of knowledge about sexually transmitted diseases (STDs): Implications for STDs prevention and care among dermatology patients in an urban city in Vietnam. International Journal of Environmental Research and Public Health, 16(6). https://doi.org/10.3390/ijerph16061080

Phulambrikar, R. M. (2018). Study of Knowledge, Attitude and Practices regarding Reproductive and Sexual Health among School Going Adolescent Girls in Rural Area of Maharashtra. Indian Journal of Youth and Adolescent Health, 05(04), $15-18$. https://doi.org/10.24321/2349.2880.201823

Randal, C., Pratt, D., \& Bucci, S. (2015). Mindfulness and Self-esteem: A Systematic Review. Mindfulness, 6(6), 1366-1378.

https://doi.org/10.1007/s12671-015-0407-6

Regis, M. F., Oliveira, L. M. F. T. de, Santos, A. R. M. Dos, Leonidio, A. da C. R., Diniz, P. R. B., \& Freitas, C. M. S. M. de. (2016). Urban versus rural lifestyle in adolescents: associations between environment, physical activity levels and sedentary behavior. Einstein (Sao Paulo, Brazil), 14(4), 461-467. https://doi.org/10.1590/S167945082016AO3788

Rogers, A. A. (2017). Parent-Adolescent Sexual Communication and Adolescents' Sexual Behaviors: A Conceptual Model and
Systematic Review. Adolescent Research Review, 2(4), 293-313. https://doi.org/10.1007/s40894-016-0049-5 Shukla, Prachi; Kang, T. K. (2017). Self-esteem among adolescents: A study of gender and locale differences. Indian Journal of Health \& Wellbeing, Vol. 8 Iss. https://web.a.ebscohost.com/abstract?direc $\mathrm{t}=$ true \&profile $=$ ehost \&scope=site\&authtyp $\mathrm{e}=$ crawler \&jrnl $=22295356 \& \mathrm{AN}=1260809$ 35\&h=0n2Oqu0nJ\%2F8J\%2BD8q5en9sE 7nRUE2ElnctjVaVbmCHJNzqR8FqUktfY Kopg9Vessih5LsRk59b5\%2BhjufaARpd $\% 2 \mathrm{Bw} \% 3 \mathrm{D} \% 3 \mathrm{D} \& \mathrm{crl}=\mathrm{c} \& \mathrm{resultNs}=\mathrm{Admin}$ WebAuth\&result

Smith, L. C., \& Okech, J. E. A. (2016). Negotiating CACREP Accreditation Practices, Religious Diversity, and Sexual Orientation Diversity: A Rejoinder to Sells and Hagedorn. Journal of Counseling and Development, 94(3), 280-284. https://doi.org/10.1002/jcad.12084

Suryoputro, A., Ford, N. J., \& Shaluhiyah, Z. (2006). Faktor-faktor yang mempengaruhi perilaku seksual remaja di jawa tengah: implikasinya terhadap kebijakan dan layanan kesehatan seksual dan reproduksi. Makara kesehatan, 10(1), 29-40.

Susanto, T., Rahmawati, I., \& Wantiyah. (2016). A community-based friendly health clinic: An initiative adolescent reproductive health project in the rural and urban areas of Indonesia. International Journal of Nursing Sciences, 3(4), 371-378. https://doi.org/10.1016/j.ijnss.2016.11.006

Thompson, E. L., Mahony, H., Noble, C., Wang, W., Ziemba, R., Malmi, M., ... Daley, E. M. (2018). Rural and Urban Differences in Sexual Behaviors Among Adolescents in Florida. Journal of Community Health, 43(2), 268-272.

https://doi.org/10.1007/s10900-017-0416-6

Van Hecke, L., Ghekiere, A., Van Cauwenberg, J., Veitch, J., De Bourdeaudhuij, I., Van Dyck, D., ... Deforche, B. (2018). Park characteristics preferred for adolescent park visitation and physical activity: A choice-based conjoint analysis using manipulated photographs. Landscape and Urban Planning, 178(July 2017), 144-155. https://doi.org/10.1016/j.landurbplan.2018. 05.017 